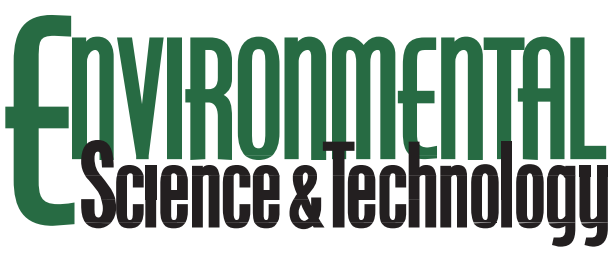

\section{Periwinkle (Littorina littorea) as a Sentinel Species: A Field Study Integrating Chemical and Biological Analyses}

\author{
Seta Noventa* and Bruno Pavoni* \\ Environmental Sciences Department, Ca’ Foscari University of Venice, Calle larga Santa Marta, Dorsoduro 2137, 30121, Venice, Italy
}

Tamara S. Galloway*

College of Life and Environmental Sciences: Biosciences, Hatherley Laboratories, University of Exeter, Prince of Wales Road, Exeter EX4 4PS, U.K.

\begin{abstract}
The gastropod Littorina littorea (common periwinkle) is an abundant and widespread North Atlantic species. The characteristic development of Intersex in L. littorea has been widely applied as a biomarker for tributyltin (TBT) contamination. Here, we assess the potential of L. littorea as a novel sentinel species for evaluating the sublethal effects in wild populations of widely distributed contaminants. We collected animals from six sites across the South coast of England. Tissue concentrations of polycyclic aromatic hydrocarbons (PAHs), organotin compounds (OTCs), polychlorinated biphenyls (PCBs), and organochlorine pesticides (OCPs) were measured and compared with biomarkers of damage to DNA (Comet assay), lysosomal stability (NRR assay), and endocrine disruption (Intersex development). There was a strong correlation between DNA damage and PAH bioaccumulation $(n=6, r=0.84, p<0.05)$, as well as that between Intersex development and OTC pollution $(n=6, r$ $=0.91, p<0.05$ ). The relationship between PAH bioaccumulation and DNA strand breaks was nonlinear, highlighting the need to consider the role of adaptive mechanisms in the interpretation of field results. These results illustrate the potential use of periwinkles for monitoring a wide range of priority pollutants.

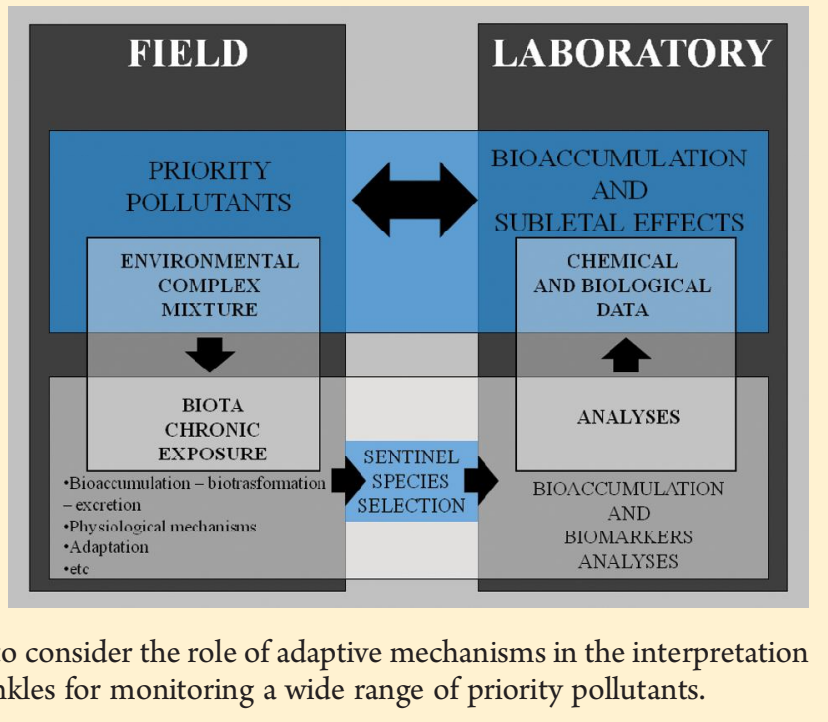

\section{INTRODUCTION}

The main aim of environmental monitoring programs is to reveal the pressure exerted by pollution on ecosystems and to assess the associated risk for human and biotic health. To achieve this goal, monitoring strategies should ideally include analyses of contaminant concentrations in biotic and abiotic samples along with the analyses of specific biomarkers designed to detect pollution-related changes at the molecular, cellular, tissue/organ, and organismal level in organisms living in poor quality environments. ${ }^{1-4}$

In the marine environment, organochlorine pesticides (OCP), polychlorinated biphenyls (PCB), polycyclic aromatic hydrocarbons (PAH), and organotin compounds (OTC) are of particular concern because of their global distribution, persistence in the environment, and tendency to bioaccumulate in biota and in some cases to biomagnify through the food chain. These pollutants are reported to cause detrimental effects to wildlife and humans, including carcinogenesis, mutagenesis, endocrine disruption, and immunotoxicity, which has resulted in the progressive restriction and limitation on their use and release at an international level (e.g., Convention on POP (2001); IMO
Convention on the control of harmful antifouling systems (2001)).$^{5,6}$ In biomonitoring programmes, the choice of species to use as sentinels is of particular importance, because trophic position, behavior, feeding habit, morphology, and habitat preference can all influence an organism's sensitivity to pollution and hence its capacity to provide insight on anthropogenic pressures on biota. ${ }^{3,7}$ Gastropod species (Mollusca) have been used mainly to biomonitor tributyltin (TBT) pollution, because of their propensity to develop the phenomena of Imposex and Intersex, in which concentration-dependent superimposition of male sexual organs onto females occurs, resulting in extreme cases in infertility and population declines. ${ }^{8-11}$ The periwinkle Littorina littorea is one of the most common North Atlantic gastropod species and is found in almost all kinds of shore (rocky, sandy, and muddy), estuaries, and mudflats, occupying areas of both the intertidal and subtidal zone (up to $15 \mathrm{~m}$ depth). ${ }^{12,13}$ Its feeding

\begin{tabular}{ll}
\hline Received: & November 25, 2010 \\
Accepted: & February 14, 2011 \\
Revised: & February 4, 2011 \\
Published: & March 14, 2011
\end{tabular}




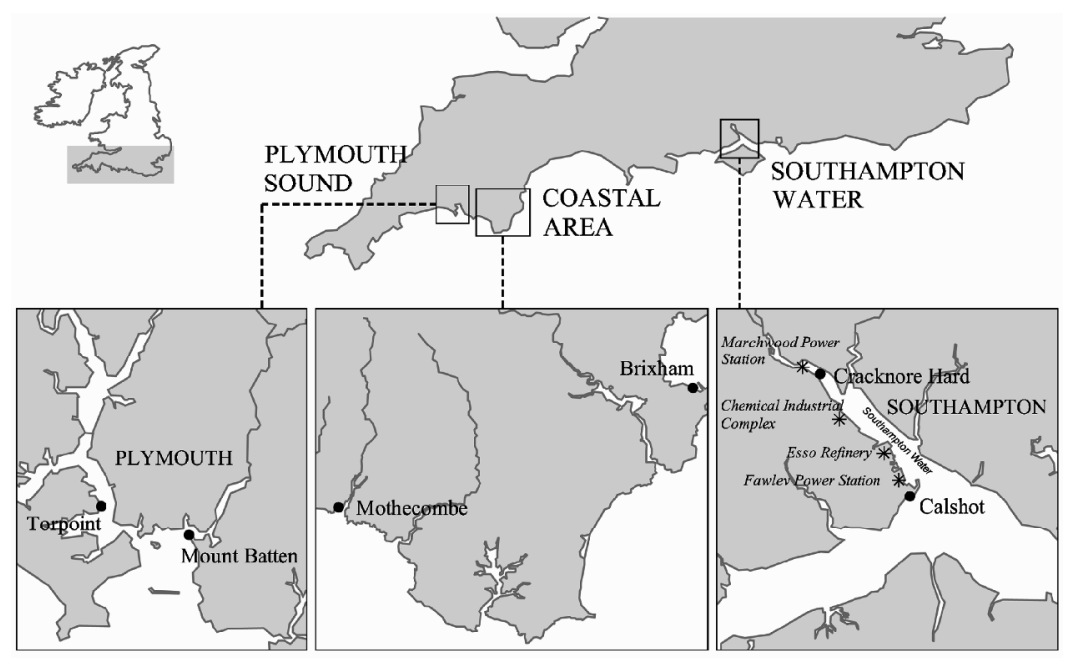

Figure 1. Geographical locations of the sampling areas and stations along the southwest English coast. GPS coordinates: Torpoint N $50^{\circ} 22^{\prime} 14^{\prime \prime}, \mathrm{W} 4^{\circ}$ $11^{\prime} 47^{\prime \prime}$; Mount Batten N 50 21 $29^{\prime \prime}$, W $4^{\circ} 7^{\prime} 47^{\prime \prime}$; Mothecombe N $50^{\circ} 18^{\prime} 44^{\prime \prime}$, W $3^{\circ} 56^{\prime} 39^{\prime \prime}$; Brixham N $50^{\circ} 24^{\prime} 7^{\prime \prime}$, W $3^{\circ} 31^{\prime} 17^{\prime \prime}$; Cracknore Hard N $50^{\circ} 53^{\prime} 45^{\prime \prime}$, W $1^{\circ} 25^{\prime} 32^{\prime \prime}$; Calshot N $50^{\circ} 48^{\prime} 46^{\prime \prime}$, W $1^{\circ} 18^{\prime} 46^{\prime \prime}$.

habit as a detritus grazer leads to ingestion of contaminants adsorbed to algae, sea-lettuce, and microorganisms, in addition to particulates and colloidal organic carbon on which many pollutants particularly hydrophobic organic contaminants tend to adsorb (refs 7 and 14 and references therein). This, together with the relatively long life span (commonly over 5 years; 17 year survival has been recorded in some habitats) highlights the potential of this species to bioaccumulate considerable quantities of hydrophobic contaminants.

Here, we assessed the novel potential of the gastropod species L. littorea as an indicator of marine environmental quality by exploring the hypothesis that chemical contaminant concentrations would be associated with specific sublethal biological effects. Chemical analyses were performed to determine the tissue concentrations of PAHs, OTCs, PCBs, and OCPs. Toxicological analyses consisted a suite of biomarkers of sublethal biological effects: DNA damage (Comet assay), cellular viability (Neutral Red Retention (NRR) assay), and endocrine disruption (Intersex Index analysis). The relationships between pollutant bioaccumulation and biological end points were explored using statistical tools, and the relative contribution provided by chemical and biological approaches for monitoring purposes was evaluated.

\section{METHODS}

Sampling. L. littorea specimens were collected from six sites along the South English coast, between March 28 and May 4, 2008 (Figure 1).

The sampling stations were chosen to represent populations of L. littorea affected by different patterns of organic contamination. Two stations, Mothecombe beach and a cove in proximity to Brixham (GPS coordinates are reported Figure 1 caption), were chosen because of their locations far from big urban and industrial areas. Mount Batten and Torpoint sites were located inside the Plymouth Sound, an open bay which receives the inflow of many tributaries (Tamar, Tavy, Lynher, Plym, and Yealm) and the pressure of anthropogenic activities concentrated in the city of Plymouth and in Devonport Dockyard. The last two sampling sites were in Southampton Water, housing major shipping terminals and numerous large industries. Sampling sites were at Cracknore Hard, between an industrial park and military port, and Calshot beach, at the mouth of the estuary.

About 140 specimens per site were collected by hand during low tide and immediately transferred to the laboratory by cold box. Twenty specimens were retained for chemical analyses, placed in a glass tank filled with artificial seawater $\left(\mathrm{T} 11^{\circ} \mathrm{C}\right.$; $3.5 \%$ salinity, constant aeration), purged overnight, and stored at $-20^{\circ} \mathrm{C}$. The remaining specimens were placed in another tank, as above, together with some leaves of algae (sea lettuce) collected in the same site, and used for the toxicological assays.

Chemical Analyses. Chemical analyses were carried out in duplicate on pooled whole body tissues (20 specimens) previously freeze-dried and homogenized. For each compound the LOD value (limit of detection) was calculated as three times the standard deviation of the concentrations revealed in the controls (blanks).

$\mathrm{PAH}, \mathrm{PCB}$, and OCP Determination. Tissue concentrations of PAHs, PCBs, and OCPs were quantified as performed by Raccanelli et al. ${ }^{15}$ The method includes ultrasonic extraction into $n$ hexane/dichloromethane (4:1) and purification through a chromatographic column (silica gel, alumina, florisil, and anhydrous sodium sulfate) which, besides removing impurities, allows the simultaneous separation of chlorinated and nonchlorinated hydrocarbons. In the extracts, PCBs and organochlorine pesticides were detected by GC-ECD (Hewlett-Packard 5890 series II, Wilmington, DE), whereas PAHs were detected by HRGC-LRMS (Hewlett-Packard 5890 series II/Hewlett-Packard 5970 B) with instrument settings as previously described. The compounds quantified for each category were the following: for PCBs, PCB 18, PCB 28, PCB 52, PCB 155, PCB 101, PCB 77, PCB 123, PCB 118, PCB 153, PCB 105, PCB 138, PCB 126, PCB 185, PCB 156, PCB 157, PCB 180, PCB 198, PCB 169, PCB 170, PCB 194, and PCB 209; for organochlorine pesticides, $\alpha$-hexachlorocyclohexane $(\mathrm{HCH}), \gamma-\mathrm{HCH}$, hexachlorobenzene (HCB), $p, p^{\prime}-1,1$-bis $(4-$ chlorophenyl-2,2-dichloroethylene) ( $p, p^{\prime}$-DDE), o,p-DDE, $p, p^{\prime}-$ 1,1-dichloro-2,2,-bis(4-chlorophenyl)ethane) ( $p, p^{\prime}$-DDD), o, $p$ DDD, $p, p^{\prime}$-1,1,1-trichloro-2,2-bis(4-chlorophenyl)ethane ( $p, p^{\prime}$ DDT) and $o, p^{\prime}$-DDT; for PAHs, naphthalene, 1-methylnaph thalene, 2-methylnaphthalene, acenaphthylene, acenaphthene, fluorene, phenanthrene, anthracene, fluoranthene, pyrene, 
benzo $[a]$ anthracene, chrysene, benzo $[b]$ fluoranthene, benzo $[k]$ fluoranthene, benzo $[a]$ pyrene, indeno $[1,2,3-c d]$ pyrene, dibenzo$[a, h]$ anthracene, and benzo[ghi]perylene. The concentrations were expressed as ng/g dry weight tissue ( $\mathrm{dw}$ ).

Organotin (OTC) Determination. Organotin compounds were analyzed as performed by Pellizzato et al. ${ }^{16}$ In summary, tributyltin (TBT), triphenyltin (TPhT), and the respective degradation products (dibutyltin (DBT), monobutyltin (MBT), diphenyltin (DPhT), and monophenyltin (MPhT)), were determined by a four-step analysis consisting of (1) extraction with a methanol solution of tropolone $(0.03 \%)$ in acid environment through a sonication bath and a liquid-liquid separation, (2) OTC derivatization with Grignard reagents ( $2 \mathrm{M}$ pentylmagnesium chloride in THF), (3) cleanup through a chromatographic column packed with florisil and anhydrous sodium sulfate, and (4) quantification by HRGC-LRMS (Hewlett-Packard 5890 series II/Hewlett-Packard $5970 \mathrm{~B}$ ) according with the operative conditions described elsewhere. Concentrations were expressed as ng $\mathrm{Sn} / \mathrm{g}$ dry weight tissue $(\mathrm{dw})$.

Biological Analyses. The Comet assay, NRR assay, and Intersex analysis were carried out on the same 20 specimens within $24 \mathrm{~h}$ from the sampling; furthermore Intersex analysis was performed on a further 80 organisms within a few days after the sampling.

Hemolymph Extraction. About $1 \mathrm{~mL}$ of hemolymph was withdrawn from each specimen by inserting a hypodermic syringe ( $1 \mathrm{~mL} ; 21$-gauge hypodermic needle) behind the ocular tentacles. Afterward the samples were placed into Eppendorf tubes filled with a few drops of saline solution (4.77 $\mathrm{g}$ of HEPES, $25.48 \mathrm{~g}$ of $\mathrm{NaCl}$, $13.06 \mathrm{~g}$ of $\mathrm{MgSO}_{4}, 0.75 \mathrm{~g}$ of $\mathrm{KCl}$, and $1.47 \mathrm{~g}$ of $\mathrm{CaCl}_{2}$ in $1 \mathrm{~L}$ of distilled water; $\mathrm{pH}$ 7.36) and kept in ice until the start of the assay (no longer than $75 \mathrm{~min}$ ). The suitability of hemolymph samples in term of cell density was checked under an optical microscope (20-50 cells per field of view, $20 \times$ objective lens).

Comet Assay. The method followed was modified from Singh et al. ${ }^{17}$ and measured single strand DNA damage under alkaline conditions at $5{ }^{\circ} \mathrm{C} .^{18}$ Briefly, cell concentrates, obtained by centrifuging about $0.5 \mathrm{~mL}$ of hemolymph samples at $1000 \mathrm{rpm}$ for $4 \mathrm{~min}$, were gently mixed with $1 \%$ low melting point agarose $\left(37^{\circ} \mathrm{C}\right)$ and smeared onto slides previously coated with $1 \%$ normal melting point agarose. Once set, cells underwent $1 \mathrm{~h}$ lysis, $45 \mathrm{~min}$ denaturation into electrophoresis solution bath (0.3 M $\mathrm{NaOH}$ and $1 \mathrm{mM}$ EDTA, $\mathrm{pH}$ 13), and a 30 min electrophoresis run (at $25 \mathrm{~V}$ and $300 \mathrm{~mA}$ ). After a short washing with the neutralizing solution ( $0.4 \mathrm{M}$ Tris, $\mathrm{pH} 7.5)$, cells were stained with $20 \mu \mathrm{L}$ of $5 \mu \mathrm{g} / \mathrm{mL}$ ethidium bromide solution and examined under a fluorescence microscope (420-490-nm excitation filter; 520-nm emission filter). One hundred cells per sample were scored using the Kinetic COMET Software. The average of DNA migration and standard deviation were calculated (mean \% tail intensity \pm SD) for each sampling site.

Neutral Red Retention (NRR) Assay. The NRR assay was performed using the in vivo cytochemical method proposed by Lowe et al. ${ }^{19}$ (International Council for the Exploration of the Sea (ICES) method No. 36). ${ }^{20}$ Briefly $40 \mu \mathrm{L}$ of hemolymph was smeared on poly-L-lysine-coated microscope slides and stained with $40 \mu \mathrm{L}$ of $0.1 \mathrm{mg} / \mathrm{mL}$ neutral red solution. After $15 \mathrm{~min}$ penetration in dark conditions, slides were systematically examined at $15 \mathrm{~min}$ intervals for the first hour, and at $30 \mathrm{~min}$ intervals for the following two hours by using a light microscope (20x objective). The end point was stated when the $50 \%$ of the cells at least exhibit either lysosomal leakages (presence of neutral red dye in cytosol) or lysosomal abnormalities (e.g., enlargements).
The mean retention time value and the standard deviation were calculated for each sampling site.

Intersex Development Analysis. Intersex analysis was carried out following ICES method No. $37 .^{21}$ One hundred specimens per site were anesthetized by exposure to $7 \% \mathrm{MgCl}_{2}$ solution and checked for sex determination. By stereoscope observation of the pallial oviduct section, females were attributed to one of the five Intersex stages:

- Stage 0: normal female without any Intersex characteristics;

- Stage 1: female with bursa copulatrix split ventrally, exposing its internal lobes;

- Stage 2: female showing the pallial oviduct (bursa copulatrix and jelly gland) split ventrally;

- Stage 3: female with the anterior part of the pallial oviduct (capsule and jelly glands with bursa copulatrix and vagina) partially or totally supplanted by a prostate gland;

- Stage 4: female carrying the characteristics of stage 3 and a penis with an open sperm groove.

Intersex Index (ISI) was calculated as mean value of Intersex stages recorded in the sampled population.

Statistical Analyses. Spatial variations of toxicological results were assessed through the analysis of variance (one-way ANOVA coupled with Tukey's posthoc test; the Kruskal-Wallis test coupled with the Mann-Whitney test), whereas the relationships between bioaccumulation pattern and health impairments through correlation analysis (Pearson correlation analysis; Spearman correlation analysis). Statistical significance was considered at the $<5 \%$ level. The statistical package STATISTICA version 7.1 (StatSoft Italy srl, 2005) was used for the analyses.

\section{RESULTS}

Chemical Analyses Results. Chemical results, summarized in Table1, revealed that the six L. littorea populations had accumulated different concentrations of organic pollutants. The most polluted site was Cracknore Hard, where $1131 \pm 23 \mathrm{ng} / \mathrm{g} \mathrm{dw}$ as total concentration of organic pollutants was recorded. Elsewhere the total pollutant residues were lower, ranging between $59 \pm 9$ and $200 \pm 6 \mathrm{ng} / \mathrm{g} \mathrm{dw}$. The least contaminated populations were those not placed under the direct influence of big urban and industrial pollution sources (Mothecombe, $58 \pm 9 \mathrm{ng} / \mathrm{g} \mathrm{dw}$; Brixham, $92 \pm 10 \mathrm{ng} / \mathrm{g} \mathrm{dw}$; Mount Batten, $59 \pm 3 \mathrm{ng} / \mathrm{g} \mathrm{dw})$.

$\mathrm{PAH}$ and OTC were the main contaminants bioaccumulated by the snails. PAH body burden was the highest in Cracknore Hard $(812 \pm 15 \mathrm{ng} / \mathrm{g} \mathrm{dw})$, whereas in all other stations it ranged between $32 \pm 2$ and $154 \pm 5 \mathrm{ng} / \mathrm{g} \mathrm{dw}$.

The proportion of individual PAH compounds is displayed in Figure 2a. Compared to the other stations, the pattern of PAH bioaccumulation in Calshot and Cracknore Hard featured a greater abundance and proportion of high molecular weight $\mathrm{PAH}$ (i.e., fluoranthene (FA), pyrene (PY), benzo[a]anthracene (BaA), chrysene (CHR), benzo[b]fluoranthene (BbFA), benzo $[k]$ fluoranthene $(\mathrm{BkFA})$, benzo $[a]$ pyrene $(\mathrm{BaP})$, indeno$[1,2,3-c d]$ pyrene (IP), benzo[ghi]perylene (BghiP)) and suggested a different origin of PAH contamination in Southampton Water, probably linked to the presence of pyrogenic sources. $^{22}$

As for PAH, OTC chemical analyses showed Cracknore Hard to have the highest OTC tissue residue $(265 \pm 17 \mathrm{ng} \mathrm{Sn} / \mathrm{g} \mathrm{dw})$, with a similar proportion of TBT and degradation products $(86$ $\pm 9 \mathrm{ng} \mathrm{Sn} / \mathrm{g}$ dw of TBT; $93 \pm 12 \mathrm{ng} \mathrm{Sn} / \mathrm{g}$ dw of DBT; $81 \pm 7$ 
Table 1. Results of Chemical and Biological Analyses: Tissue Residues of Organic Pollutants on Periwinkles (20 organism pools) and Biomarkers Responses ${ }^{a}$

\begin{tabular}{|c|c|c|c|c|c|c|c|c|}
\hline & \multicolumn{5}{|c|}{ chemical analyses } & \multicolumn{3}{|c|}{ biological analyses } \\
\hline & $\begin{array}{c}\text { PAH } \\
(\mathrm{ng} / \mathrm{g} \mathrm{dw})\end{array}$ & $\begin{array}{c}\text { OTC } \\
(\mathrm{ng} \mathrm{Sn} / \mathrm{g} \mathrm{dw})\end{array}$ & $\begin{array}{c}\text { PCB } \\
(\mathrm{ng} / \mathrm{g} \mathrm{dw})\end{array}$ & $\begin{array}{c}\text { OCP } \\
(\mathrm{ng} / \mathrm{g} \mathrm{dw})\end{array}$ & $\begin{array}{l}\sum \text { organic } \\
\text { pollutants } \\
(\mathrm{ng} / \mathrm{g} \mathrm{dw})\end{array}$ & $\begin{array}{l}\text { comet assay, mean } \\
\text { percentage tail intensity } \\
\qquad( \pm \mathrm{SD})(\%)\end{array}$ & $\begin{array}{l}\text { NRR assay, mean } \\
\text { retention time } \\
( \pm \mathrm{SD})(\mathrm{min})\end{array}$ & $\begin{array}{c}\text { intersex, } \\
\text { ISI }( \pm S D)\end{array}$ \\
\hline MOTHECOMBE & $47 \pm 9$ & $4\left(^{*}\right)$ & $5.9 \pm 0.2$ & $1.2 \pm 0.2$ & $58 \pm 9$ & $4 \pm 2$ & $75 \pm 25$ & $0.1 \pm 0.3$ \\
\hline BRIXHAM & $35 \pm 4$ & $45 \pm 9$ & $4.4 \pm 0.5$ & $7.4 \pm 0.4$ & $92 \pm 10$ & $10 \pm 7$ & $47 \pm 21$ & $0.4 \pm 0.8$ \\
\hline MOUNTBATTEN & $32 \pm 2$ & $12 \pm 2$ & $11.3 \pm 0.7$ & $4.2 \pm 1.0$ & $59 \pm 3$ & $10 \pm 4$ & $18 \pm 6$ & $0.5 \pm 0.5$ \\
\hline TORPOINT & $69 \pm 20$ & $59 \pm 7$ & $18.4 \pm 0.7$ & $7.3 \pm 1.1$ & $154 \pm 21$ & $7 \pm 3$ & $14 \pm 8$ & $0.5 \pm 0.5$ \\
\hline CALSHOT & $154 \pm 5$ & $40 \pm 4$ & $5.3 \pm 1.1$ & $1.6 \pm 0.2$ & $200 \pm 6$ & $17 \pm 7$ & $13 \pm 5$ & $0.2 \pm 0.4$ \\
\hline CRACKNORE HARD & $812 \pm 15$ & $266 \pm 17$ & $48.0 \pm 2.2$ & $5.7 \pm 3.9$ & $1131 \pm 23$ & $22 \pm 7$ & $13 \pm 10$ & $1.1 \pm 1.1$ \\
\hline
\end{tabular}

a The concentration of each pollutant class is the sum of each single congener's concentration; the error was calculated from the semivariation interval of the two replicates analyzed. The sign $\left({ }^{*}\right)$ marks the concentrations below the limit of detection (LOD) and was calculated by summing the semi-LOD values of the class congeners.
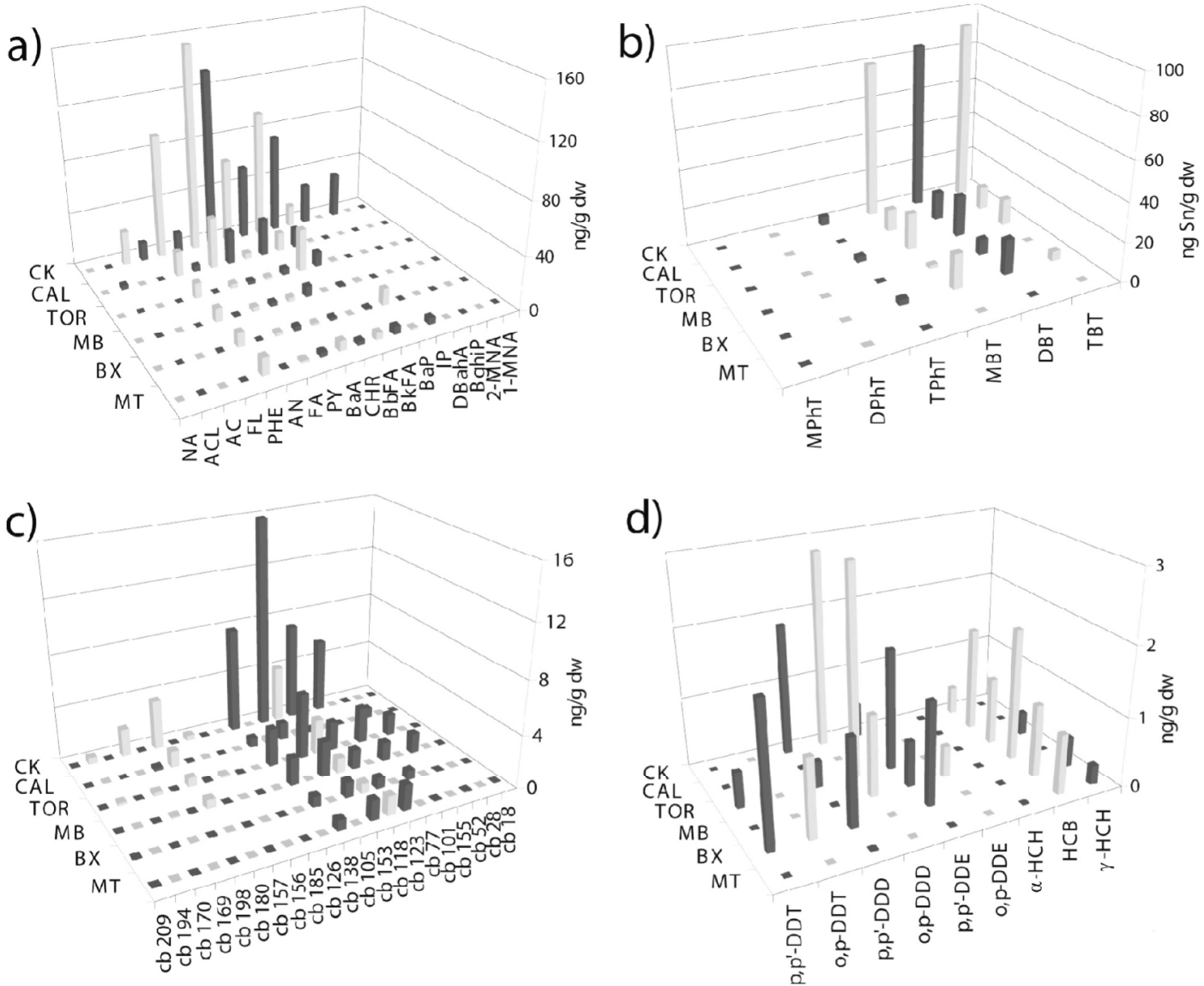

Figure 2. Bioaccumulation patterns of PAHs (graph a), OTCs (graph b), PCBs (graph c), and OCPs (graph d) in L. littorea populations (20 organism pools). Error bars were computed by propagating errors of single determinations (semivariation interval of the two replicates analyzed). Abbreviations: Mothecombe (MT), Brixham (BX), Mountbatten (MB), Torpoint (TOR), Calshot (CAL), Cracknore Hard (CK); PAHs: naphthalene (NA), 2-methylnaphthalene (2-MNA), 1-methylnaphthalene (1-MNA), acenaphthylene (ACL), acenaphthene (AC), fluorene (FL), phenanthrene (PHE), anthracene (AN), fluoranthene (FA), pyrene (PY), benzo[a] anthracene (BaA), chrysene (CHR), benzo[b]fluoranthene (BbFA), benzo$[k]$ fluoranthene (BkFA), benzo[a]pyrene (BaP), indeno[1,2,3-cd]pyrene (IP), dibenzo[a,h]anthracene (DBahA), benzo[ghi]perylene (BghiP); OTCs: tributyltin (TBT), dibutyltin (DBT), monobutyltin (MBT), triphenyltin (TPhT), diphenyltin (DPhT), monophenyltin (MPhT); OCPs: hexachlorocyclohexane (HCH), hexachlorobenzene (HCB), 1,1-bis(4-chlorophenyl)-2,2-dichloroethylene (DDE), 1,1-dichloro-2,2,-bis(4-chlorophenyl)ethane (DDD), 1,1,1-trichloro-2,2-bis(4-chlorophenyl)ethane (DDT).

ng $\mathrm{Sn} / \mathrm{g} \mathrm{dw}$ of MBT). Elsewhere OTC residues were lower (between LOD and $58.7 \mathrm{ng} \mathrm{Sn} / \mathrm{g} \mathrm{dw}$ ) and showed a more degraded pattern of contamination, featuring a larger contribution of DBT and MBT (Figure 2b). 


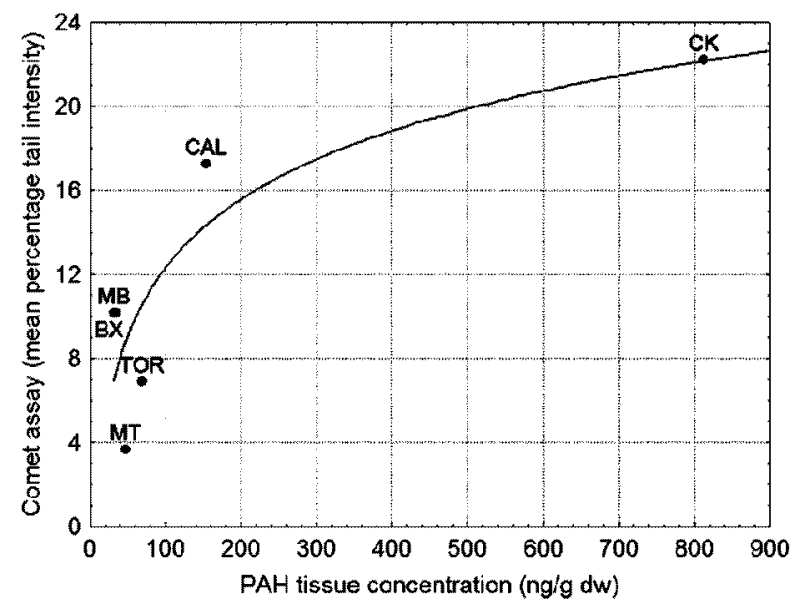

Figure 3. Scatterplot of total PAH bioaccumulation and Comet assay results.

All PCB concentrations varied within a limited range $(4.4 \pm$ 0.5 and $48.0 \pm 2.2 \mathrm{ng} / \mathrm{g} \mathrm{dw}$ as PCBs sum) and exhibited a predominance of six congeners which totally accounted for the 70.9-97.0\% (PCB 153, PCB 138, PCB 123, PCB 118, PCB 180, and $\mathrm{PCB}$ 101) (Figure 2c), whereas chlorinated pesticides constituted the pollutant class contributing the least to pollutant body burdens (Figure 2d).

Biological Analyses Results. Comet assay results (Table 1) showed Southampton Water populations (Cracknore Hard and Calshot) to be affected by similar genotoxic stress $(p>$ $0.05)$, greater than all other populations $(p<0.05)$. Periwinkles from Mothecombe, Brixham, and Plymouth Sound (Mount Batten and Torpoint) had a similar degree of DNA fragmentation $(p>0.05)$.

With regard to the NRR assay results (Table 1), periwinkles showed poor lysosomal stability (retention time $<20 \mathrm{~min}$ ) across all sites except Mothecombe and Brixham where retention times of $>45$ min were recorded, indicating good physiological status. In particular, the Mothecombe population reported the highest mean retention time $(75 \pm 25 \mathrm{~min})(p<0.05)$.

Females showing Intersex features were found at all sites, with the Cracknore Hard population showing the greatest degree of masculinization and the highest ISI value (Table 1$)(p<0.05)$. The degree of malformation in the remaining populations was generally low: mainly normal and stage 1 females were observed across the other sites.

Relationships between Organic Pollutant Bioaccumulation and Sublethal Effects. Consistent with the well-characterized genotoxic potential of $\mathrm{PAHs}^{2.3}$ and endocrine activity of organotin compounds, ${ }^{24}$ the variation of DNA integrity among the populations correlated strongly with the average of total PAH residues in their tissues $(n=6, r=0.84, p<0.05)$, whereas Intersex development correlated with total OTC tissue concentrations $(n=6, r=0.91, p<0.05)$. Differently, the results of the NRR assay did not show a significant relationship with the pollutant residues in periwinkles $(p>0.05)$. As shown by the scatterplot in Figure 3, the correlation between the level of PAH in the tissues and the degree of DNA fragmentation is logarithmic. A more detailed analysis looking for relationships between the specific pattern of PAH body burden and the degree of genotoxic stress did not reveal a different role of petrogenic and pyrogenic congeners in inducing DNA damage.

\section{DISCUSSION}

Sensitivity of L. littorea to Organic Pollutants. This study was undertaken to examine the potential of $L$. littorea as a sentinel organism, using a studying approach that integrated both chemical and biological analyses. The results showed that the various sublethal effects measured in periwinkles were associated with the presence of widely distributed priority contaminants.

The sensitivity of $L$. littorea to TBT pollution is widely known, and the relationship between Intersex development and TBT environmental levels has been assessed by field and laboratory experiments. ${ }^{10}$ The present survey showed that, despite the overall decreasing levels of OTC pollution due to the international ban of TBT-based antifouling paints, ${ }^{25,26}$ OTC-contaminated areas still exist and so the use of a sentinel species that develop TBT-induced effects can provide important advantages. The great level of TBT and degradation products in Cracknore Hard (Figure $2 \mathrm{~b}$ ), in fact, suggested the presence of an active TBT source, which might be identified in the military port located in the proximity of the sampling site (Marchwood military port). In fact, the regulations of TBT-based antifouling systems (i.e., European Regulation (EC) No. 782/2003 and International Convention on the control of harmful antifouling systems on ships (AFS convention, 2001)) did not phase out the use of these products on army ship's hulls. It is also possible that the anoxic muddy sediment and the sheltered morphology of the area contributed to keep high OTC levels by reducing degradation processes. The correlation found between Intersex development and total OTC tissue concentrations, rather than with TBT body burden, might be explained considering that, in the sea, DBT and MBT originate mainly from TBT degradation (considering irrelevant PVC as a source), and so the OTC body burden is almost representative of the initial TBT presence, the effective agent of Intersex induction. A similar result has also been observed in studies using different gastropod species. ${ }^{15}$

The strong correlation found between DNA fragmentation and $\mathrm{PAH}$ bioaccumulation illustrates the sensitivity of $L$. littorea to $\mathrm{PAH}$ pollution. The genotoxic activity of $\mathrm{PAH}$ compounds is well-known, ${ }^{23}$ and it has been assessed in field and laboratory experiments using different aquatic organisms and biomarkers of genotoxicity. ${ }^{27-31}$ Interestingly, the present results show a nonlinear relationship between PAH concentrations in tissues and the extent of single-stranded DNA breaks in these wild organisms. In fact, in agreement with other studies, ${ }^{29,31}$ the level of DNA fragmentation in Cracknore Hard was not statistically higher than that recorded in Calshot, despite the former having almost 5-fold higher PAH tissues residues than the latter. This might speculatively be explained by the occurrence of adaptation mechanisms in chronically exposed populations, such as upregulation of DNA repair mechanisms, a suggestion supported by both field evidence ${ }^{29,32}$ and transplantation experiments ${ }^{33}$ with other molluscan species. In this context, the use of a wider biomarker battery to more fully characterize the extent and nature of genetic lesions (e.g., chromosomal injuries, mutations, micronucleus formation) would be merited.

As regards the NRR assay, the results obtained here showed a more favorable health condition of periwinkles sampled far away from big urban and industrial pollution sources (coastal area) compared to that of populations from Plymouth and Southampton area. The lack of a strict correlation with pollutant bioaccumulation can be explained considering that lysosomal membrane instability is a general biomarker of organismal health 
that can be induced by many chemical and nonchemical stressors acting separately or simultaneously. However, the nonspecific information provided by this biomarker is generally considered highly valuable for wide-scale biomonitoring programs, as demonstrated by its primary role as a "screening" biomarker in multitier approaches. ${ }^{34}$ It would be of interest in future studies to probe the functional significance of these alterations in periwinkles, for example by assessing immunocompetence and rates of infection, since prolonged instability of hemocyte lysosomes can reduce immune competence because of the central role of phagocytosis and lysosomal degradation in degrading damaged cellular materials and pathogens. ${ }^{35,36}$

In conclusion, the results of this field survey encourage the use of periwinkles as a novel sentinel of marine quality. Thanks to its abundance and resistance to environmental contamination, $L$. littorea occupies wide geographical areas and allows biomonitoring of both pristine and poor quality sites. The significant relationship seen between sublethal biological effects and bioaccumulation of priority pollutants illustrates the usefulness of L. littorea as a bioindicator of pollution. Comparison between chemical and biological results showed that for some contaminants, these associations are nonlinear, highlighting the need to further consider the role of adaptation mechanisms in wild organisms occupying polluted sites.

\section{AUTHOR INFORMATION}

\section{Corresponding Author}

*E-mail: setanoventa@stud.unive.it; B.Pavoni@unive.it (B.P.); t.s.galloway@exeter.ac.uk (T.S.G.). Phone: ++39041 2348597 (S.N.).

\section{REFERENCES}

(1) Cajaraville, M. P.; Bebianno, M. J.; Blasco, J.; Porte, C.; Sarasquete, C.; Viarengo, A. The use of biomarkers to assess the impact of pollution in coastal environments of the Iberian Peninsula: a practical approach. Sci. Total Environ. 2000, 247, 295-311.

(2) Downs, C. A.; Dillon, R. T.; Fauth, J. E.; Woodley, C. M. A molecular biomarker system for assessing the health of gastropods (Ilyanassa obsoleta) exposed to natural and anthropogenic stressors. J. Exp. Mar. Biol. Ecol. 2001, 259, 189-214.

(3) Galloway, T. S.; Brown, R. J.; Browne, M. A.; Dissanayake, A.; Lowe, D.; Depledge, M. H.; Jones, M. B. The ECOMAN project: A novel approach to defining sustainable ecosystem function. Mar. Pollut. Bull. 2006, 53, 186-194.

(4) Lam, P. K. S.; Gray, J. S. The use of biomarkers in environmental monitoring programmes. Mar. Pollut. Bull. 2003, 46, 182-186.

(5) Livingstone, D. R. Contaminant-stimulated reactive oxygen species production and oxidative damage in aquatic organisms. Mar. Pollut. Bull. 2001, 42 (8), 656-666.

(6) Vasseur, P.; Cossu-Leguille, C. Linking molecular interactions to consequent effects of persistent organic pollutants (POPs) upon populations. Chemosphere 2006, 62, 1033-1042.

(7) Baumard, P.; Budzinski, H.; Garrigues, P.; Sorbe, J. C.; Burgeot, T.; Bellocq, J. Concentrations of PAHs (Polycyclic Aromatic Hydrocarbons) in various marine organisms in relation to those in sediments and to trophic level. Mar. Pollut. Bull. 1998, 36 (12), 951-960.

(8) Bryan, G. W.; Gibbs, P. E.; Hummerstone, L. G.; Burt, G. R. The decline of the gastropod Nucella lapillus around the south-west England: evidence for the effect of tributyltin from antifouling paints. J. Mar. Biol. Assoc. U.K. 1986, 66, 611-640.

(9) Gibbs, P. E.; Bryan, G. W. The reproductive failure in populations of the dog-whelk, Nucella lapillus, caused by Imposex induced by tributyltin from antifouling paints. J. Mar. Biol. Assoc. U.K. 1986, 66, 767-777.

(10) Oehlmann, J.; Schulte-Oehlmann, U. Endocrine disruption in invertebrates. Pure Appl. Chem. 2003, 75 (11-12), 2207-2218.

(11) Schipper, C. A.; Smit, M. G. D.; Kaag, N. H. B. M.; Vethaak, A. D. A weight-of-evidence approach to assessing the ecological impact of organotin pollution in Dutch marine and brackish waters; combining risk prognosis and field monitoring using common periwinkles (Littorina littorea). Mar. Environ. Res. 2008, 66 (2), 231-239.

(12) Bauer, B.; Fioroni, P.; Die, I.; Liebe, S.; Oehlmann, J.; Stroben, E.; Watermann, B. TBT effects on the female genital system of Littorina littorea: a possible indicator of tributyltin pollution. Hydrobiologia 1995, 309, 15-27.

(13) Gorbushin, A. M.; Iakovleva, N. V. Haemogram of Littorina littorea. J. Mar. Biol. Assoc. U.K. 2006, 86, 1175-1181.

(14) Lowe, D. M.; Moore, M. N.; Readman, J. W. Pathological reactions and recovery of hepatopancreatic digestive cells from the marine snail Littorina littorea following exposure to a polycyclic aromatic hydrocarbon. Mar. Environ. Res. 2006, 61, 457-470.

(15) Raccanelli, S.; Pavoni, B.; Maroli, L.; Sfriso, A. One step cleanup and separation of chlorinated, aliphatic, and polycyclic aromatic hydrocarbons in environmental samples, prior to gas chromatographic quantification. Toxicol. Environ. Chem. 1994, 45, 121-137.

(16) Pellizzato, F.; Centanni, E.; Marin, M. G.; Meschino, V.; Pavoni, B. Concentrations of organotin compounds and Imposex in the gastropod Hexaplex trunculus from the Lagoon of Venice. Sci. Total Environ. 2004, 332, 89-100.

(17) Singh, N. P.; McCoy, M.; Tice, R. R.; Schneider, E. L. A simple technique for quantitation of low levels of DNA damage in individual cells. Exp. Cell. Res. 1988, 175, 184-191.

(18) Lewis, C.; Galloway, T. Genotoxic damage in polychaetes: a study of species and cell-type sensitivities. Mutat. Res. 2008, 654, $69-75$.

(19) Lowe, D. M.; Moore, M. N.; Evans, B. M. Contaminant impact on interactions of molecular probes with lysosomes in living hepatocytes from dab Limanda limanda. Mar. Ecol.: Prog. Ser. 1992, 91, 135-140.

(20) Moore, M. N.; Lowe, D.; Köhler, A. Biological effects of contaminants: Measurement of lysosomal membrane stability. ICES Tech. Mar. Environ. Sci. 2004, 36, 31.

(21) Oehlmann, J. Biological effects of contaminants: use of Intersex in the periwinkle (Littorina littorea) as a biomarker of tributyltin pollution. ICES Tech. Mar. Environ. Sci. 2004, 37, 22.

(22) Francioni, E.; Wagener, A.de.L.R.; Scofield, A. L.; Depledge, M. H.; Cavalier, B. Evaluation of the mussel Perna perna as a biomonitor of polycyclic aromatic hydrocarbon (PAH) exposure and effects. Mar. Pollut. Bull. 2007, 54, 329-338.

(23) Xue, W.; Warshawsky, D. Metabolic activation of polycyclic and heterocyclic aromatic hydrocarbons and DNA damage: a review. Toxicol. Appl. Pharmacol. 2005, 206, 73-93.

(24) Oehlmann, J.; Di Benedetto, P.; Tillmann, M.; Duft, M.; Oetken, M.; Schulte-Oehlmann, U. Endocrine disruption in prosobranch molluscs: evidence and ecological relevance. Ecotoxicology $2007,16,29-43$.

(25) Sousa, A.; Laranjeiro, F.; Takahashi, S.; Tanabe, S.; Barroso, C. M. Imposex and organotin prevalence in a European post-legislative scenario: temporal trends from 2003 to 2008. Chemosphere 2009, $77,566-573$.

(26) Oliveira, I. B.; Richardson, C. A.; Sousa, A. C.; Takahashi, S.; Tanabe, S.; Barroso, C. M. Spatial and temporal evolution of Imposex in dogwhelk Nucella lapillus (L.) populations from North Wales, UK. J. Environ. Monitor 2009, 11 (8), 1462-1468.

(27) Aas, E.; Baussant, T.; Balk, L.; Liewenborg, B.; Andersen, O. K. PAH metabolites in bile, Cytochrome P4501A and DNA adducts as environmental risk parameters for chronic oil exposure: a laboratory experiment with Atlantic cod. Aquat. Toxicol. 2000, 51, 241-258.

(28) Kim, I. Y.; Hyun, C. K. Comparative evaluation of the alkaline comet assay with the micronucleus test for genotoxicity monitoring using aquatic organisms. Ecotox. Environ. Safe 2006, 64, 288-297. 
(29) Large, A. T.; Shaw, J. P.; Peters, L. D.; McIntosh, A. D.; Webster, L.; Mally., A.; Chipman, J. K. Different levels of mussel (Mytilus edulis) DNA strand breaks following chronic field and acute laboratory exposure to polycyclic aromatic hydrocarbons. Mar. Environ. Res. 2002, 54, 493-497.

(30) Mitchelmore, C. L.; Birmelin, C.; Chipman, J. K.; Livingstone, D. R. Evidence for cytochrome P-450 catalysis and free radical involvement in the production of DNA strand breaks by benzo[a]pyrene and nitroaromatics in mussel (Mytilus edulis L.) digestive gland cells. Aquat. Toxicol. 1998, 41, 193-212.

(31) Akcha, F.; Tanguy, A.; Leday, G.; Pelluhet, L.; Budzinski, H.; Chiffoleau, J. F. Measurement of DNA single-strand breaks in gill and hemolymph cells of mussels, Mytilus sp., collected on the French Atlantic Coast. Mar. Environ. Res. 2004, 58, 753-756.

(32) McFarland, V. A.; Inouye, L. S.; Lutz, C. H.; Jarvis, A. S.; Clarke, J. U.; McCant, D. D. Biomarkers of oxidative stress and genotoxicity in livers of field-collected brown bullhead, Ameiurus nebulosus. Arch. Environ. Contam. Toxicol. 1999, 37, 236-241.

(33) Shaw, J. P.; Large, A. T.; Livingstone, D. R.; Doyotte, A.; Renger, J.; Chipman, J. K.; Peters, L. D. Elevation of cytochrome P450immunopositive protein and DNA damage in mussels (Mytilus edulis) transplanted to a contaminated site. Mar. Environ. Res. 2002, 54, 505-509.

(34) Viarengo, A.; Lowe, D.; Bolognesi, C.; Fabbri, E.; Koehler, A. The use of biomarkers in biomonitoring: A 2-tier approach assessing the level of pollutant-induced stress syndrome in sentinel organisms. Comp. Biochem. Phys. C 2007, 146, 281-300.

(35) Grundy, M. M.; Ratcliffe, N. A.; Moore, M. N. Immune inhibition in marine mussels by polycyclic aromatic hydrocarbons. Mar. Environ. Res. 1996, 42 (1-4), 187-190.

(36) Fernley, P. W.; Moore, M. N.; Lowe, D. M.; Donkin, P.; Evans, S. Impact of the Sea Empress oil spill on lysosomal stability in mussel blood cells. Mar. Environ. Res. 2000, 50, 451-455. 